\title{
DIGITAL ECONOMY
}

Cisko L., JUDr., PhD. SITÁR \& SALOKA, Attorneys at Law

Košice, Slovak Republic

DOI: https://doi.org/10.30525/978-9934-26-068-1-34

\section{DIGITALIZATION OF PROCESSES IN THE EUROPEAN ECONOMIC AREA}

The central aim of this contribution is to approximate recent views focused on the regulation, respectively transformation of processes in the context of a phenomenon such as digitalization. The purpose of carrying out processes such as particularly artificial intelligence, data and on-line platforms (in the broadest sense), is their use inter alia in the framework to increase the competitiveness of the European economy as a whole, including the technological progress of the Member States of the European Union.

In its essence, this is a sphere that must be given due attention both at the institutional level of the European Union and at the level of its Member States. With regard to the interdisciplinary dimension of the analyzed issues, which in terms of the scope of processing deserves monographic processing, we focus on relevant European law-making, including interactions and inspirational legislative impulses from national (Slovak) legislation, specifically in the context of normative processes within de lege ferenda considerations.

In the framework of the expanding electronic communication are coming to the foreground, especially in the business sphere, increasingly legitimate demands (expectations), to be the virtual space sufficiently regulated and secured. In connection with the emergence of the COVID-19 pandemic (hereinafter in text referred to as the «pandemic»), the idea of digitalization has changed fundamentally in civil society and the economy as such. 
The pandemic also revealed the vulnerabilities of the digital space within the European Economic Area, its dependence on non-European technologies and the impact of misinformation on our democratic societies. In this context, it must be said that Europe's way to a digital economy and society is about solidarity, prosperity and sustainability, rooted in strengthening the rights of its citizens and enterprises [1] and ensuring the security and resilience of its digital ecosystem and supply chains [2, p. 96].

In the sense of the 2030 Digital Compass, can be clearly so to speak learned from the consequences of a pandemic, as the benefit of digitalization is to connect people no matter where they are physically located. Digital infrastructure and fast connectivity can bring new opportunities. The European Commission is proposing to set up a digital compass that will transform the European Union's digital ambitions by 2030 into specifically goals and ensure that they are met. The compass will be based on an improved monitoring system to track the trajectory of the European Union in terms of the tempo of digital transformation, gaps in Europe's strategic digital capacities, as well as the implementation of digital principles.

These areas are: Digitally qualified population and highly qualified digital professionals; Secure and performance sustainable digital infrastructures; Digital transformation of enterprises; Digitalization of public services.

At this place, it should be emphasized that digital technology represents access to a practically unrestricted market in the framework of exchange of goods and providing services. A positive product for the implementation of the goals is thus a substantial increase in competitiveness in its essence of all industries. The supposed result should certainly be economic growth and prosperity.

Simultaneously, must be taken into account that the presumed action of entities via digital (on-line) technologies must primarily reflect the legislation by functional regulation of legal norms focused principally on personal data protection [3], cyber security of data transmission [4], support of activities in the provision of mass financing services for entrepreneurship [5] etc. 
At the level of the Member States of the European Union, specifically in the Slovak Republic, for the development of the national economy deserves special attention the digitalization of processes within the so-called e-Government (creation of the so-called functional bureaucracy). It's primarily a matter of adopting specific normative legal acts [6] for the favorable development of digital public-benefit services and ensuring the use of digital instruments and systems for effective and targeted providing of modern e-Government, both for the citizens of the European Union and for commercial companies, respectively in company law [7].

In this context we want to give attention that in the Slovak Republic is (currently) ongoing the process of recodification of private law. Its (successful) result should be, inter alia according to the latest legislative proposals, the regulation of legal forms of commercial companies in the new act.

In the context of the thematic focus of this contribution, it's desirable to state that the above mentioned corporate law has been significantly affected by digitalization, and that in three directions. Based on Legislative intention of recodification the company law are sequentially electronicized activities of public administration in the registration of commercial companies; is supported the possibility of performance members' rights at a distance while increasing legal certainty as to the possibilities and conditions for performing the rights of members at a distance; from the strictly regulated method of raising capital is separated financing of companies through platforms, e. g.: crowdinvestment [8].

It's clear that quality law-making, in connection with relevant trends in the Europeanization of private law, can positively influence (improve) legal relations with an emphasis on economic aspects. However, implementation will require a broader professional discussion. By establishing a (modern) legal regulation, both at the supranational level and in the environment of the legislation of the Member States of the European Union, taking into account technological progress, will be possible to achieve a functional digital economy, respectively high-speed infrastructure in the near future. 
This concerns the special time frame after the successful overcoming of the pandemic in the so-called post-crisis period. Some suggestions presented in this article are to be understood only in terms of academic opinions and de lege ferenda proposals.

\section{References:}

1. To the conceptual definition of enterprise: KUBÍČEK, P.: Pojem podnik z aspektu práva. In: Obchodné spoločnosti - aktuálne otázky a problémy. Plzeň: Aleš Čeněk, str. 103 a nasl., 2008.

2. Communication from the Commission to the European Parliament, the Council, the European Economic and Social Committee and the Committee of the Regions. 2030 Digital Compass: the European way for the Digital Decade. COM/2021/118 final. European Commission. Done at Brussels, 9 March 2021. Hereinafter in text referred to as "2030 Digital Compass". At this place, we want to point out that the power of the European Commission's legislative initiative doesn't extended only to the procedural aspects (to the right to submit a proposal for a legal act), but also in a material context that is to have the right to determine its content. In: JÚDA, V.: Rozsah a limity právomoci Komisie pri prijímaní záväzných právnych aktov Únie. In: FINĎOVÁ, E. (ed.): Nové trendy v práve I. Zborník príspevkov z medzinárodnej vedeckej konferencie konanej 7. - 8. apríla 2016 na Právnickej fakulte Univerzity Mateja Bela v Banskej Bystrici. Právnická fakulta Univerzity Mateja Bela v Banskej Bystrici. Banská Bystrica, Belianum, 2016.

2. Especially: Consolidated text: Regulation (EU) 2016/679 of the European Parliament and of the Council of 27. April 2016 on the protection of natural persons with regard to the processing of personal data and on the free movement of such data and repealing Directive 95/46/EC (General Data Protection Regulation). Text with EEA relevance. Done at Brussels, 27 April 2016.

3. In particular: Joint Communication to the European Parliament, the European Council and the Council. Increasing resilience and bolstering capabilities to address hybrid threats. JOIN(2018)16 final. European Commission. Done at Brussels, 13 June 2018.

4. Regulation (EU) 2020/1503 of the European Parliament and of the Council of 7 October 2020 on European crowdfunding service providers for business, and amending Regulation (EU) 2017/1129 and Directive (EU) 2019/1937. Text with EEA relevance. Done at Brussels, 7 October 2020. It shall apply from 10 November 2021.

5. See mainly: Act No. 305/2013 Coll. on the electronic form of the performance of powers of public authorities and on the amending and supplementing of certain acts (the e-Government Act); Act No. 95/2019 Coll. on information technologies in public administration and on the amending and supplementing of certain acts. In wider contexts to these legal norms see the scientific study: KUBINCOVÁ, T. LIPTÁKOVÁ, K.: Informatizácia verejnej správy $\mathrm{v}$ kontexte ukladania a správy miestnych daní a miestnych poplatkov. In: TULÁČEK, J. (ed.): Aktuálne otázky 
územnej samosprávy v podmienkach Slovenskej republiky. Elektronický zborník vedeckých štúdií. Praha: Leges, str. 269 a nasl., 2020.

6. In this context see in particular: Legislative intention of recodification the company law. Working group for the recodification of company law. Ministry of Justice of the Slovak Republic. LP/2020/627. March 2021. Hereinafter in text referred to as «Legislative intention of recodification the company law». To the legal status of commercial companies in the Slovak Republic see: ĎURICA, M.: Obchodné spoločnosti: $§ 56-68$ (okrem $\S 66 \mathrm{a}, 66 \mathrm{~b}$ ). In: Obchodný zákonník: Komentár. 4. aktualizované vydanie. Bratislava: C. H. Beck, str. 209 a nasl., 2013.

7. To commercial legal obligations in investment banking and to financial and commodity derivatives see in particular: LIŠKA, P. - ELEK, Š. - MAREK, K.: Bankovní obchody. Wolters Kluwer, 216 s., 2014. 